\title{
Evaluation of ApPlication of New Decision-Making Methods in Selected Companies: The Use of Business Intelligence in PraCtice
}

\author{
Petra Kašparová \\ Technical University of Liberec, Faculty of Economics, \\ Department of Business Administration and Management, \\ Studentská 1402/2, 46117 Liberec, Czech Republic \\ e-mail: petra.kasparova1@ @ul.cz
}

\begin{abstract}
Growing pressure on increasing decision-making speed in all spheres of human life is one of the basic phenomena of today. Immediately after the first wave of the coronavirus pandemic, we can consider the ability of making good decisions quickly as one of the most important aspects of our being. The main objective of this article is to find out the utilization rate of several basic decision-making approaches in selected companies with an emphasis on newly used methods such as data analysis and business intelligence tools. The first part of the article presents a short introduction of the decision-making process and an overview of hitherto known and used tools facilitating the whole procedure. The submitted study of available literature leads to the presentation of own classification of the most widely used decisionmaking methods. Based on a questionnaire survey, in the second section, the pilot research examines the involvement of five different groups of methods in business decision-making, such as intuition and previous experiences, consultation with colleagues, data analysis (historical), MCDM methods and consultation with experts. Afterwards, the most common obstacles that employees must face in introducing new tools have been identified. In general, the results show that time and the associated pressure on decision-making speed play a crucial role in the decision-making process.
\end{abstract}

\section{Keywords}

Decision-making process; Decision-making methods; Business intelligence; Mann-Whitney test.

\section{Introduction}

The result of the current development is a technologically complex production and a diverse offer in the segment of services with high demands on managerial decision-making. The phenomenon of growing pressure on the speed of decision-making is caused by increasing demands placed on not only companies and thereby individual employees, but the entire society. New and complex technologies play a key role at all stages of business processes. New factors influencing managerial work are also emerging. Modern managers must take into account the social, environmental or, for example, demographic consequences of their decisions [1].

For these reasons, it is no longer sufficient for management to solely use management tools commonly identified by literature, e.g. Pareto Analysis, the exchange of ideas, guided discussion, mathematical-logical models, etc., and there is pressure to develop other methods.

Therefore, the presented list of methods also includes new approaches that support managerial decision-making. New developing and advanced computer technologies help change the organizational structure within the organization, set up the re-engineering process or directly 
change management methods. Chen mentioned the significance of business intelligence and analytics in both academic and business communities. Further, the main opportunities associated with data and analysis are highlighted. It helps to reveal crucial business data to facilitate an enterprise's better understanding of its business and market and timely business decisions [2]. The findings obtained from another research recommend managers to focus on five crucial factors to gain greater profitability from business intelligence projects: BI solutions must be built with end users in mind, BI system needs to be closely tied to a company's vision, projects need to be properly scoped and prioritized, all technological issues need to be solved and non-technological issues should be avoided [3].

Isik provided a better understanding of the relationship between the decision environment and BI capabilities. According to the study outcomes, organizations must pay attention to the consideration of incorporating the necessary flexibility in decision making processes supported by BI, even for structured operational decisions. The results highlighted the importance of paying attention to business intelligence's technical and organizational capabilities involving the provision of appropriate user access to BI resources and ensuring the seamless integration of BI with other systems [4].

In order to fulfil the purposes of this article, its structure is as follows. After the short introduction, a brief literature review is presented. The second section includes the methodology used for this study, providing an overview of the research instrument. The third section focuses on mapping the current stance towards using these methods in selected companies, which represents the main goal of the article. Based on a questionnaire survey conducted among employees across the fields of business and working levels, evaluation of currently used tools will be performed with an emphasis on new approaches primarily using data analysis and business intelligence principles. The obtained results and data analysis are presented. At the end, a short conclusion with limitations and plans for future research is drawn.

\section{$1 \quad$ Literature Review}

The literature summary is divided into three sections. First, basic characteristics of the decision-making process are introduced, followed by a brief overview of the implemented methods and concluding with the self-determined proposal for sorting of methods.

\subsection{Decision-Making Process}

At a time when all technologies and knowledge are essentially available to everyone, human capital remains one of the few competitive advantages. Ambient pressure comes not only from competitors, but also from customers, suppliers and the public. The manager is faced with an environment in which the following factors are manifested [1]:

- growing competition,

- more complex operational and business environment,

- variability of customer requirements,

- changing markets,

- growing information needs,

- rising costs of incorrect decisions,

- declining reliability of forecasts.

All these trends together place high demands on the manager's ability to make the right decisions, predict future development and co-create a corporate vision. 
The procedure for resolving a selected decision problem describes the decision process in detail. Individual activities and their content are closely connected with the structure of the decision-making process, they follow in time and can be divided into individual stages. The concept of individual phases and their division in the literature differs according to the author.

Blažek divides the whole process into 6 phases, which are divided into two larger subgroups according to the applied principle of thinking and the type of work with information [5]:

- divergent thinking, expanding the set of information:

$\circ$ the definition phase (setting goals),

$\circ$ the analysis phase (an overview of relevant and available information), and

$\circ$ the generation phase (a list of variants).

- convergent thinking, reducing the volume of information:

$\circ$ the classification phase (sorting options),

$\circ$ the evaluation phase (selection and use of a suitable decision-making method, recommendations leading to the selection of the most suitable alternative), and

$\circ$ the decision phase.

\subsection{Decision-Making Methods}

A huge number of publications dealing with decision-making in the business environment can be found in literature and professional journals. Some resources only address a selected set of methods, while others provide a summary overview. Examples mentioned hereinafter in this section only represent a brief selection of known and used methods.

One of the principles for sorting a large number of techniques available in several publications is a classification of methods according to the proportion of mathematics necessary for their application. Occam's razor, brainstorming, brainwriting, and the Delphi method stand at the beginning of this order. The next group includes the Pareto principle, cost-benefit analysis (CBA), and business intelligence (BI). Quantitative methods and mathematical models constitute a separate branch of decision analysis. These approaches utilize sophisticated mathematical programs, computer software, and/or principles of artificial intelligence [6].

Other authors examine multi-criteria decision making methods in their studies published in scholar journals most frequently. For example, a publication that comprehensively lists the following methods and their subsequent application [7]: AHP (analytic hierarchy process), ANP (analytic network process), SAW (simple additive weighting), TOPSIS (technique for order preference by similarity to ideal solution), ELECTRE (elimination and choice expressing reality) and PROMETHEE, GRA (gray relational model), fuzzy integral technique, rough sets, structural model. Another example, the handbook Multiple Criteria Decision Analysis (MCDA): State of the Art Surveys, presents well-established methodologies and theories and it divides literature streams dedicated to this topic as follows: MCDA today, foundations of MCDA, outranking methods, multi-attribute utility theory, nonclassical MCDA approaches, multi-objective mathematical programming, applications, and MCDM software [8].

The authors frequently devote themselves to one method or a group of methods applied for the specific problem or situation. Table 1 shows a few such papers from recent times. 
Tab. 1: Outcomes of earlier studies

\begin{tabular}{|c|c|c|c|}
\hline Title & Author(s) & $\begin{array}{l}\text { Year of } \\
\text { publication }\end{array}$ & Objective of the paper \\
\hline $\begin{array}{l}\text { Decision Making } \\
\text { Methods Based on } \\
\text { Fuzzy Aggregation } \\
\text { Operators: Three } \\
\text { Decades Review from } \\
1986 \text { to } 2017\end{array}$ & $\begin{array}{l}\text { Mardani Abbas et } \\
\text { al. [9] }\end{array}$ & 2018 & $\begin{array}{l}\text { Systematic review of articles } \\
\text { dealing with fuzzy set theory } \\
\text { and aggregation operator } \\
\text { theory. }\end{array}$ \\
\hline $\begin{array}{l}\text { Sensitivity Curve of the } \\
\text { Decision-Making } \\
\text { Process of a Company }\end{array}$ & $\begin{array}{l}\text { Karel Chadt and } \\
\text { Martin Petříček } \\
{[10]}\end{array}$ & 2018 & $\begin{array}{l}\text { Measurement capabilities for } \\
\text { sensitivity of the decision- } \\
\text { making process within the } \\
\text { issue of the use of quantitative } \\
\text { methods. }\end{array}$ \\
\hline $\begin{array}{l}\text { Stochastic Multi- } \\
\text { Criteria Decision- } \\
\text { Making: An Overview } \\
\text { to Methods and } \\
\text { Applications }\end{array}$ & $\begin{array}{l}\text { Erkan Celik, } \\
\text { Muhammet Gul, } \\
\text { Melih Yucesan \& } \\
\text { Suleyman Mete } \\
{[11]}\end{array}$ & 2019 & $\begin{array}{l}\text { A comprehensive view on } \\
\text { stochastic multi-criteria } \\
\text { decision-making in respect to } \\
\text { showing up-to-date literature. }\end{array}$ \\
\hline $\begin{array}{l}\text { Modelling procedure } \\
\text { for the selection of steel } \\
\text { pipes supplier by } \\
\text { applying fuzzy AHP } \\
\text { method }\end{array}$ & $\begin{array}{l}\text { Kazimieras } \\
\text { Zavadskas, E., } \\
\text { Turskis, Z., } \\
\text { Stević, Željko, \& } \\
\text { Mardani, A. [12] }\end{array}$ & 2020 & $\begin{array}{l}\text { The study used fuzzy Analytic } \\
\text { Hierarchy Process to choose } \\
\text { the optimal supplier for the } \\
\text { purchase of materials necessary } \\
\text { for the production of pre- } \\
\text { insulated pipes. }\end{array}$ \\
\hline
\end{tabular}

Source: Own

\subsection{A Proposal of Decision-Making Method Classification}

Based on the analysis of the presented literature, a possible approach to the classification of methods facilitating managerial decision-making is shown below. Most authors only deal with the detailed breakdown in the decision-making process in the variant evaluation phase. The proposed classification shown in Figure 1 is based on the concept of the decision-making process mentioned above.

The presented structure offers a comprehensive view that would include all types of methods. However, it is not intended to list all available tools and procedures. This is almost impossible in today's world, where new methods are constantly being developed or those already known are being advanced. 


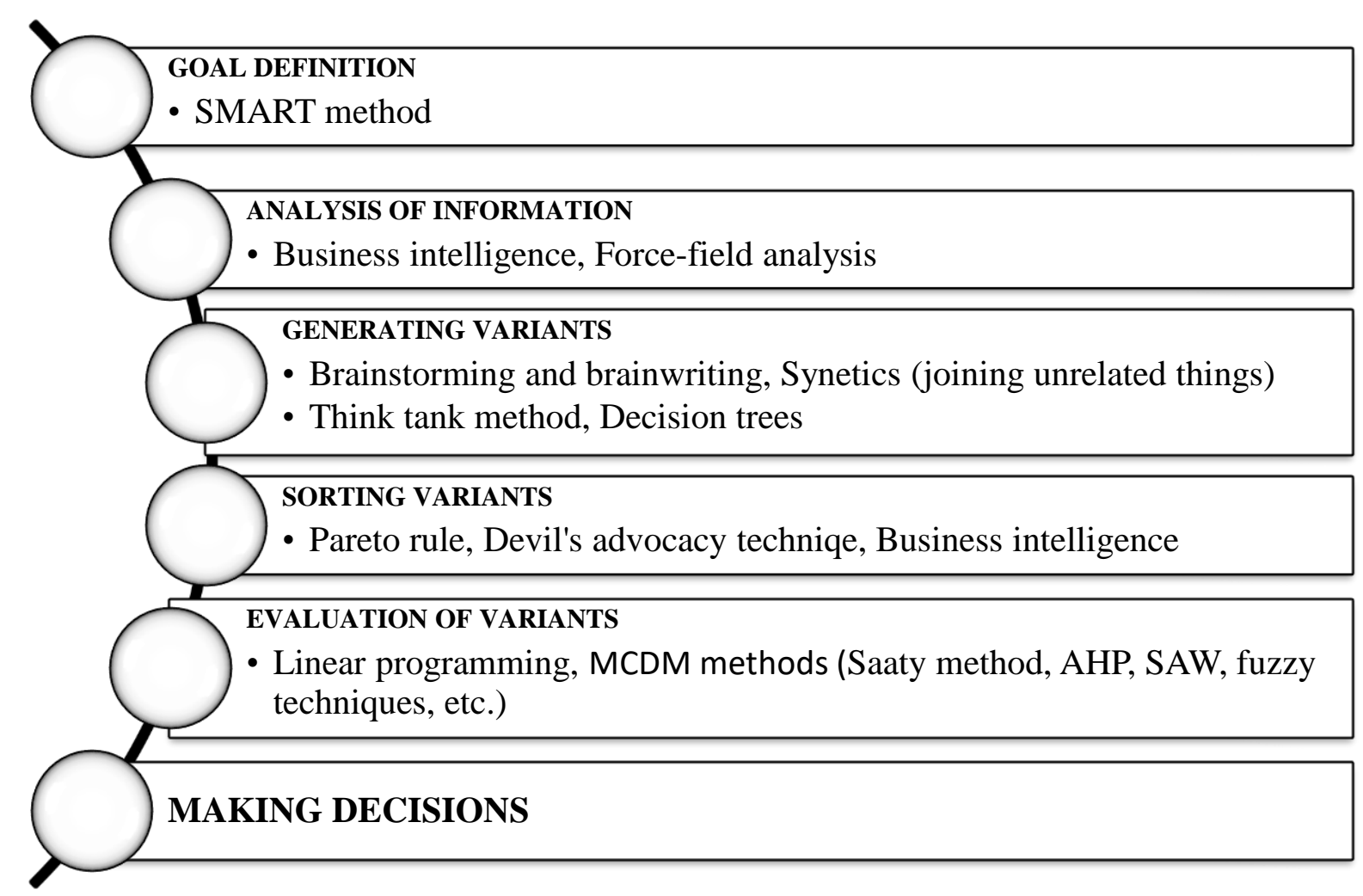

Source: Own

Fig. 1: Classification of decision-making methods

\section{Research Methodology}

The pilot research was conducted in several phases. First, a questionnaire was compiled containing questions covering the main topics of long-term research. The data was further processed using several statistical methods and the results are presented in the following section.

\subsection{Questionnaire Survey}

The questionnaire survey is ranked among the methods of quantitative research that enable researchers to obtain a large amount of information from a larger number of respondents in a shorter period of time than, for example, an interview. For this study, three basic types of questions were used. The respondents usually replied to yes or no questions, chose from a finite number of alternatives, or the Likert scale representing the degree of agreement was used.

A total of 90 questionnaires were distributed among employees, of which 75 completed forms could be included in the analysis. The respondents were contacted through the HR department and through a LinkedIn work network. This professional network was selected as a comprehensive source of respondents across business fields and job levels within the organizational structure.

The selection was made on a voluntary basis. The employees could work in the same organization, but they worked in different departments. This method is one of the least invasive techniques used when a relatively small sample is needed. The sample corresponds to the interest of the respondents. The risk is low representativeness and also the fact that similar personalities can report [13]. However, companies do not want to provide this type of 
data. Accordingly, for the presented research, this sample was found to be sufficient and the results serve for the first idea of the researched topic within the long-term research.

The initial set of questions presented in the questionnaire focused on obtaining basic information about each employee. The aim was to classify respondents by the size of the enterprise, the business sector, their department and the usage of information systems within their company, not only in the decision-making process.

The methods of descriptive statistics (frequencies) are applied to describe the basic set. Tables 2 and 3 show the distribution of respondents according to the size of their organization and the classification of job positions in the organizational structure.

Tab. 2: Distribution of respondents by enterprise size

Enterprises by business size

\begin{tabular}{lr}
\hline Micro and small sized enterprises (0-49 employees) & 7 \\
\hline Medium-sized enterprises (50 to 249 employees) & 15 \\
\hline Large enterprises (more than 250 employees) & 53 \\
\hline Own
\end{tabular}

Source: Own

Tab. 3: Distribution of respondents by job level

Source: Own

\begin{tabular}{lc}
\hline Job level & Number of respondents \\
\hline Executive management & 8 \\
\hline Middle management & 21 \\
\hline Line management & 6 \\
\hline Specialists & 40 \\
\hline
\end{tabular}

In the next section, respondents expressed their agreement with statements on the five-point Likert scale, where the highest value meant strong agreement and the lowest value total disagreement, as has been shown in Table 4.

Tab. 4: Likert scale

$*$

$* *$

$* * *$

$* * * *$

$* * * * *$

Consent rate Strongly disagree Disagree Neutral Agree Strongly agree

Source: Own

To confirm some differences between specific groups of respondents, the list of jobs has only been transferred to two groups: specialists and management members. After conversion, the new distribution looked like this: 43 specialists and 32 management members. To verify possible significant difference these hypotheses have been determined as follows:

$H_{0}$ : There is no difference between the opinions of specialists and managers on the selected statement.

$H_{1}:$ A difference between the opinions of specialists and managers exists on the selected statement.

\subsection{Mann-Whitney U test}

The Mann-Whitney U test (sometimes called the Mann Whitney Wilcoxon Test) has been applied by means of Statgraphics, since a non-parametric test allows two groups or conditions or treatments to be compared without making the assumption that values are normally distributed. Non-parametric tests test the null hypothesis, which only concerns the general properties of the distribution of the monitored quantity in statistical files. Non-parametric tests 
are also suitable for ordinal variables, which are evaluated by a subjective scale of values [14].

\section{$3 \quad$ Research Objectives}

The main objective of this article is to find out the utilization rate of several basic decisionmaking approaches in selected companies with emphasis on newly used methods such as data analysis and business intelligence tools.

\section{$4 \quad$ Research Results}

One of the series of questions was devoted to the use of decision-making methods in practice. The respondents could choose from 5 different types of methods and complete the "Others" column as well. They could mark off any number of tools. The list of possibilities and their frequencies is presented in Table 5.

Tab. 5: List of methods

\begin{tabular}{lc}
\hline Method(s) based on & Total frequencies (out of 75) \\
\hline Intuition and previous experiences & 61 \\
\hline Consultation with colleagues & 50 \\
\hline Data analysis (historical) & 47 \\
\hline Multi-criteria decision-making (MCDM) methods & 19 \\
\hline Consultation with experts outside of the company & 14 \\
\hline Others & 2 \\
\hline
\end{tabular}

Source: Own

At first sight, the results show a close link between the lack of time, which is an integral part of all business sectors, and the pressure exerted on rapid decision-making. When making decisions, most respondents rely on their own intuition, their own experience and advice from their colleagues. According to the summary of frequencies in Table 5, more complex and time-consuming methods are less frequently used.

On average, the respondents selected 2.5 methods and slight differences between managers and specialists were determined. Figure 2 shows the results:

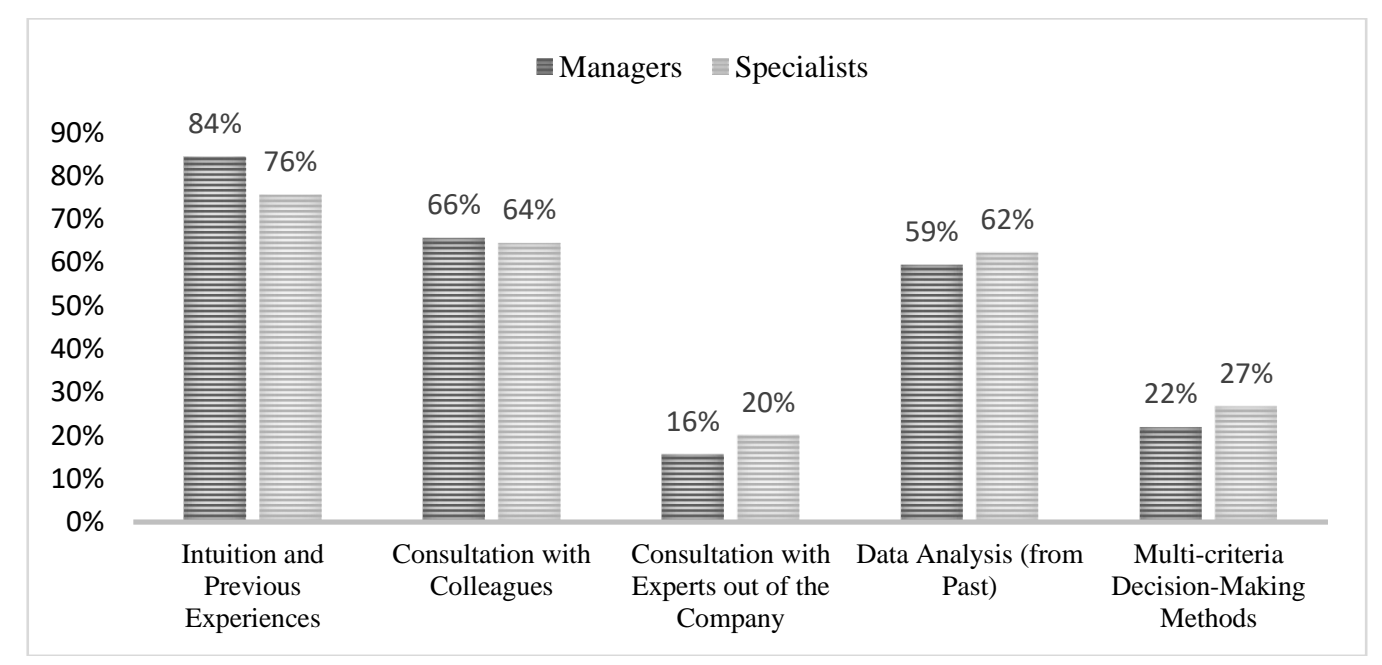

Source: Own

Fig. 2: Utilization of methods (relative frequency)

Managers are often considered to be the main users of results gained by data analysis and business intelligence tools. They often serve as a basis for decision-making based on MCDM. 
Hence, quite surprisingly, a larger share of users of data analysis and MCDM methods was recorded among specialists than among managers.

The outcomes of the comparison confirm the phenomenon mentioned above. There is not enough time left to apply more complex decision-making methods for both researched groups. Employees at all levels are often forced to make so-called ad-hoc decisions based on previous experience and intuition. This is also most likely due to the growing pressure caused by the rapid development of technology, increased demand for products and services and, thereby, increasing requirements imposed on employees and managers.

If we build on the previous chart, the strong expression of dissatisfaction with data consolidation and interconnection of systems by managers is worth mentioning. The measured value of agreement with the statement 'I would welcome a wider data connection of individual IS with subsequent presentation of results' averaged 3.9. In contrast, the average measured value for specialists was 3.4. The statistical significance of the difference has been verified by the Mann-Whitney test on two independent samples:

Mann-Whitney (Wilcoxon) W-test to compare medians. The W value equates to 479.5 and the $P$-value $=0.0204921$. Since the $P$-value is less than 0.05 , there is a statistically significant difference between the medians at the $95.0 \%$ confidence level.

Thus, the results show that although managers have or should have more power to introduce new tools to facilitate the decision-making process, they are the ones who would welcome more support. Another series of questions sought to reveal the obstacles that employees must face in introducing new tools. The histogram in Figure 3 shows the most indicated difficulties by both managers and specialists. They could mark off any number of obstacles. On average, members of both groups selected about 2 of them.

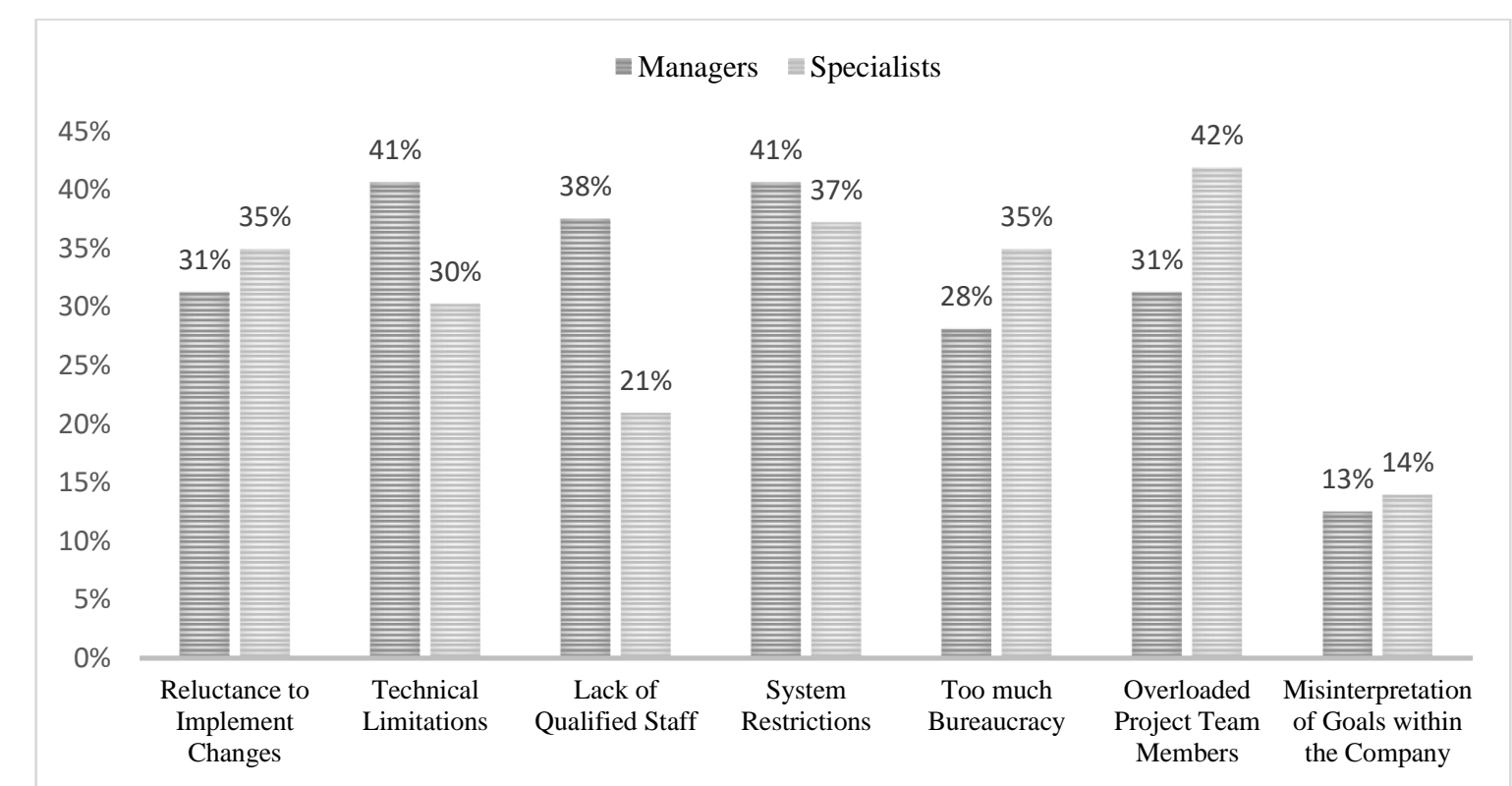

Source: Own

Fig. 3: Indication of obstacles by managers and specialists (relative frequency)

In this group of questions, the discrepancy of opinion was most pronounced. While specialists most often point out the overload of individual employees within project teams, managers, on the other hand, lack enough qualified staff and further mention technical limitations and system restrictions. Disagreements can be partially explained by common different perceptions of work effort made and the required commitment from the manager's point of view. On the other hand, a clear warning from ordinary workers about their overload cannot 
be neglected, and more than a third also point out excessive bureaucracy (35\%) and even more negatively perceive system barriers (37\%), where agreement was found within both groups (managers 41\%). Almost a third additionally cite 'reluctance to changes' as a major obstacle, which is a crucial warning for top management in the current complex, rapidly changing business environment.

\section{$5 \quad$ Limitations}

The research contains several limitations. First, the selection of respondents made on a voluntary basis could not ensure the required representativeness. However, the results may indicate certain contexts of behavior, which can then be verified in further research. The questionnaire was also structured with an emphasis on comprehensibility in order to reach the widest possible range of respondents. It limited the possibilities of wider data analysis. In the next phase of the research, it is planned to address a specific group of employees dedicated to the implementation of new methods, and to examine the factors and reasons influencing the use of these methods in greater detail.

\section{Conclusion}

This article was intended to present the structure of the decision-making process, classification of the most common tools supporting the continuality of the process, and finally to find the rate of use of decision-making methods in selected companies.

The most frequently used methods have been arranged into six categories based on phases defined in a decision-making process structure available in appropriate literature. The division of these tools varies across authors. Most of them only deal with one of the categories of these methods and rather prefer a detailed insight into the issues of each specific method. A similar introduction of decision-making methods comparable to the presented article has been divided into 5 sections. It likewise begins with a description of the decision-making process. In the next section, the importance of making a distinction between the cases as to whether we have a single criterion or multiple criteria and between a finite or infinite number of feasible alternatives is highlighted. On the contrary, particular methods are only categorized in three groups as follows: Multi-attribute decision making methods, Group decision making, and Sensitivity analysis [15].

The main goal of the article was to present the utilization rate of decision-making methods in Czech companies. The analysis based on the results obtained from a questionnaire represents the main contribution of this article. In general, the outcomes show that time plays a crucial role in the decision-making process.

The research showed the involvement of five different groups of methods in business decision-making (intuition and previous experiences, consultation with colleagues, data analysis (historical), multi-criteria decision-making methods, consultation with experts outside of the company) with an emphasis on new methods using data analysis and business intelligence principles. The use of this type of tool also revealed the most common obstacles related to its implementation from both the manager and the specialist's sides. Specialists highlighted overloading of project teams most whereas managers emphasized technical limitations and system restrictions with the same high frequency.

Primarily all respondents, regardless their work position, would currently appreciate the wider connection of available data. However, they commonly rely on their own experience and advice from colleagues. They therefore choose the fastest decision option. Comparable research to the presented study was conducted in 2017 [16]. The cited article particularly discusses the attitude of selected small and medium-sized enterprises towards business 
intelligence systems. A total of 96 subjects were included in the analysis, and the results from a questionnaire survey revealed that business intelligence systems are not too widespread or familiar among the selected group of small- and medium-sized enterprises. The research also showed that most companies do not even need to implement more sophisticated software tools, because the analyses they perform fully suit the management. Both research papers showed the satisfaction of companies that have already used BI tools. They confirmed better access to information, better decision-making and, thereby, a competitive advantage compared to others.

On the other hand, enterprises face enormous pressures and are continuously striving for innovative and effective material management methods. Upcoming research can explore why companies do not frequently use new decision-making methods, particularly business intelligence principles that can signify an important market advantage. Future research can set up a model to show these organizations how to incorporate business intelligence methods to improve decision-making processes.

\section{Acknowledgements}

This work was supported by SGS 21345: "Application of Business Intelligence in Corporate Processes" provided by the Technical University of Liberec, Czech Republic.

\section{Literature}

[1] POKORNÝ, M.: Nekonveční metody řešení ekonomických a manažerských úloh. Olomouc: Univerzita Palackého v Olomouci, 2014.

[2] CHEN, H.; CHIANG, R. H. L.; STOREY, V. C.: Business Intelligence and Analytics: From Big Data to Big Impact. MIS Quarterly. 2012, Vol. 36, Issue 4. DOI: $10.2307 / 41703503$

[3] ADAMALA, S; CIDRIN, L.: Key Success Factors in Business Intelligence. Journal of Intelligence Studies in Business. 2011, Vol. 1, Issue 1. DOI: 10.37380/jisib.v1i1.19

[4] ISIK, O.; JONES, M. C.; SIDOROVA, A.: Business Intelligence (BI) Success and the Role of BI Capabilities. International Journal of Intelligent Systems in Accounting and Finance Management. 2011, Vol. 18, Issue 4. DOI: $\underline{\text { 10.1002/isaf.329 }}$

[5] BLAŽEK, L.: Management: organizování, rozhodování, ovlivňování. Praha, Grada, 2011. ISBN 978-80-247-4429-2.

[6] ŠTĚDROŇ, B. et al.: Manažerské rozhodování v praxi. C.H.Beck. 2015. ISBN 978-807400-587-9.

[7] TZENG, G.-H.; HUANG, J.-J.: Multiple Attribute Decision Making. Methods and Applications. Chapman and Hall/CRC, 2011. ISBN 9781439861578.

[8] FIGUEIRA, J.; GRECO, S.; EHROGOTT, M. (ed.): Multiple Criteria Decision Analysis: State of the Art Surveys. Springer Science \& Business Media, 2005. DOI: $\underline{10.1007 / \mathrm{b} 100605}$

[9] MARDANI, A.; NILASHI, M.; ZAVADSKAS, E. K.; AWANG, S. R.; ZARE, H.; JAMAL, N. M.: Decision Making Methods Based on Fuzzy Aggregation Operators: Three Decades Review from 1986 to 2017. International Journal of Information Technology \& Decision Making (IJITDM). 2018, Vol. 17, Issue 2, pp. 391-466 DOI: $\underline{10.1142 / \mathrm{S} 021962201830001 \mathrm{X}}$ 
[10] CHADT, K.; PETŘÍČEK, M.: Sensitivity curve of decision-making process of the company. ACC Journal. 2018, Vol. 24, Issue 2, pp. 40-46. DOI: $10.15240 /$ tul/004/2018-2-004

[11] CELIK, E.; GÜL, M.; YÜCESAN, M.; METE, S.: Stochastic multi-criteria decisionmaking: an overview to methods and applications. Beni-Suef University Journal of Basic and Applied Sciences. 2019, Vol. 8, Article number 4. DOI: 10.1186/s43088-019$\underline{0005-0}$

[12] ZAVADSKAS, E. K.; TURSKIS, Z.; STEVIĆ, Ž.; MARDANI, A.: Modelling procedure for the selection of steel pipes supplier by applying fuzzy AHP method. Operational Research in Engineering Sciences: Theory and Applications. 2020, Vol. 3, Issue 2, pp. 39-53. DOI: 10.31181/oresta2003034z

[13] REICHEL, J.: Kapitoly metodologie sociálních výzkumů. Praha: Grada, 2009.

[14] FVHE: Biostatistika. [online]. [accessed 2020-04-13]. Available from WWW: https://cit.vfu.cz/stat/FVHE/prednasky.htm

[15] FÜLÖP, J.: Introduction to Decision Making Methods. Laboratory of Operations Research and Decision Systems, Computer and Automation Institute, Hungarian Academy of Sciences. [online]. 2000. Available from WWW: https://www.academia.edu/22906650/Introduction_to_Decision_Making_Methods

[16] NOSKOVÁ, M.: Business Intelligence a jeho využití při řízení MSP. (Business Intelligence and its Application in the Management of SME). Trendy v podnikání. (Business Trends). [online]. 2017, Vol. 7, Issue. 2, pp. 18-27. Available from WWW: https://dspace5.zcu.cz/bitstream/11025/29146/1/Noskova.pdf 


\section{VYHODNOCENII VYUŽITÍ NOVÝCH ROZHODOVACÍCH METOD VE VYBRANÝCH SPOLEČNOSTECH}

Stoupající tlak na rozhodování ve všech sférách lidského života se řadí mezi základní fenomény současné doby. Nejen ve firmách je tento jev způsoben zvyšujícími se nároky kladenými na celou společnost a potažmo na jednotlivé pracovníky. Článek v první části předkládá přehled doposud známých a užívaných nástrojů, které pracovníkům usnadňují jednu ze základních, dnes již nejen manažerských, funkcí - rozhodování. Na základě dostupné literatury dospěje předložená rešerše $\mathrm{k}$ představení vlastního návrhu možného rozřazení nejuživanějších rozhodovacích metod. Samotné zmapování jednotlivých nástrojů by však nebylo kompletní, pokud by využití těchto metod nebylo ověřeno v praxi. Hlavním cílem tohoto článku je zanalyzovat aplikaci několika základních metod rozhodování ve vybraných podnicích s důrazem na nově využívané nástroje, jako je datová analýza a principy business intelligence.

\section{BEWERTUNG DER ANWENDUNG NEUER ENTSCHEIDUNGSMETHODEN IN AUSGEWÄHLTEN UNTERNEHMEN}

Der wachsende Druck, in allen Bereichen des menschlichen Lebens Entscheidungen zu treffen, ist eines der Grundphänomene von heute. Dieses Phänomen wird nicht nur in Unternehmen durch steigende Anforderungen an das gesamte Unternehmen und damit an einzelne Mitarbeiter verursacht. Der folgende Artikel gibt im ersten Teil einen Überblick über bisher bekannte und verwendete Instrumente, die den Mitarbeitern eine der grundlegenden Funktionen erleichtern, die heute nicht nur Führungskräfte betrifft, nämlich die Entscheidungsfindung. Basierend auf der verfügbaren Literatur gelangt die vorliegende Recherche zu einem eigenen Vorschlag für eine mögliche Einteilung der am häufigsten verwendeten Entscheidungsfindungsmethoden. Die Erfassung der einzelnen Instrumente allein wäre jedoch nicht vollständig, wenn die Verwendung dieser Methoden in der Praxis nicht verifiziert wäre. Das Hauptziel dieses Artikels besteht darin, die Anwendung einiger grundlegender Entscheidungsfindungsmethoden in ausgewählten Unternehmen zu analysieren, wobei der Schwerpunkt auf neu verwendete Instrumente wie Datenanalyse und Business Intelligence-Prinzipien liegt.

\section{OCENA STOSOWANIA NOWYCH METOD PODEJMOWANIA DECYZJI W WYBRANYCH SPÓŁKACH}

Rosnący nacisk na podejmowanie decyzji we wszystkich sferach ludzkiego życia to jeden z głównych fenomenów dzisiejszych czasów. Nie tylko w firmach zjawisko to jest spowodowane rosnącymi wymaganiami stawianymi całemu przedsiębiorstwu, a w konsekwencji także poszczególnym pracownikom. Niniejszy artykuł w pierwszej części przybliża dotąd poznane i używane narzędzia, które ułatwiają pracownikom realizację jednej z podstawowych, dziś już nie tylko, menedżerskich funkcji - podejmowanie decyzji. Na podstawie dostępnej literatury $\mathrm{w}$ dalszej części niniejszego opracowania przedstawiona została własna propozycja możliwej klasyfikacji najczęściej używanych metod podejmowania decyzji. Sam przegląd poszczególnych narzędzi nie byłby jednak kompletny bez sprawdzenia zastosowania tych metod w praktyce. Głównym przedmiotem niniejszego artykułu jest analiza zastosowania kilku podstawowych metod podejmowania decyzji w wybranych przedsiębiorstwach ze szczególnym uwzględnieniem stosowania nowych narzędzi, takich jak analiza danych i zasady business intelligence. 